\title{
Multilayer Graphene Oxide-Silver Nanoparticle Nanostructure as Efficient Peroxidase Mimic
}

\section{Etkili Peroksidaz Taklitçi Olarak Çok Tabakalı Grafen Oksit-Gümüş Nanopartikül Nanoyapısı}

\author{
Research Article
}

Burak Derkus $^{1 *}$, Pinar Acar Bozkurt²

'Department of Biomedical Engineering, Engineering Faculty, Eskisehir Osmangazi University, Eskisehir, Turkey. ${ }^{2}$ Science Faculty, Department of Chemistry, Ankara University, Ankara, Turkey.

\begin{abstract}
A B S TR ACT
n this work, platinum ( $\mathrm{Pt}$ ), titanium $(\mathrm{Ti})$ and silver $(\mathrm{Ag})$ doped graphene oxide $(\mathrm{GO})$ nanostructures were synthesized by using sonochemical technique, a relatively new technique in nanomaterial synthesis, and characterized in detail. The synthesized nanomaterials were characterized utilizing transmission electron microscopy (TEM) and X-ray photoelectron spectroscopy (XPS). TEM images and XPS spectras showed that the dopping process was successful. In addition, a multilayer graphene oxide-silver nanoparticles (M-GOAgNPs) nano-structure was synthesized in this study for the first time, and it's electrochemical performance was compared with GO-AgNPs. As a result of electrochemical study, the rate constants of the GO-AgNPs and M-GO-AgNPs modified electrodes were found as $\mathrm{ks}_{\text {anodic }}=6.62 \mathrm{~s}^{-1}$ and $\mathrm{ks}_{\text {anodic }}=6.78 \mathrm{~s}^{-1}$, respectively. Finally, the M-GO-AgNPs nano-structure obtained by sonochemical technique, a green chemistry synthesis technique, has been found to be suitable for use as an electrochemical sensor matrix.
\end{abstract}

\section{Key Words}

Graphene oxide, silver, platinum, titanium, nanoparticle, sonochemistry, green chemistry.

\section{öz}

u çalışmada, nanomalzeme sentezinde nispeten yeni bir teknik olan sonokimyasal tekniğin kullanılmasıyla platin (Pt), titanyum ( $\mathrm{Ti}$ ) ve gümüş $(\mathrm{Ag})$ doplanmış grafen oksit (GO) nano-yapılar sentezlenmiş ve detaylı bir şekilde karakterize edilmiştir. Sentezlenen nano-malzemeler transmisyon elektron mikroskobu (TEM) ve X-ışınları fotoelektron spektroskopisi (XPS) ile karakterize edilmiştir. TEM görüntüleri ve XPS spektrumları doplama işleminin başarılı bir şekilde gerçekleştiğini göstermiştir. Ayrıca bu çalışmada ilk kez çok tabakalı grafen oksit-gümüş nanopartikül nano-yapısı (M-GO-AgNPs) sentezlenmiş ve elektrokimyasal performansı GOAgNPs ile karşılaştırılmıştır. Elektrokimyasal çalışmalar sonucunda GO-AgNPs ve M-GO-AgNPs hız sabitleri sırası ile $\mathrm{ks}_{\text {anodik }}=6.62 \mathrm{~s}^{-1}$ ve $\mathrm{ks}_{\text {anodik }}=6.78 \mathrm{~s}^{-1}$ olarak bulunmuştur. Sonuç olarak bir yeşil kimya sentez tekniği olan sonokimyasal teknik ile elde edilen M-GO-AgNPs nano-yapının elektrokimyasal sensör matriksi olarak kullanım için uygun olduğu görülmüştür.

\section{Anahtar Kelimeler}

Grafen oksit, gümüş, platin, titanyum, nanopartikül, sonokimya, yeşil kimya.

Article History: Received: Jan 06, 2018; Revised: Jan 23, 2018; Accepted: Jan 29, 2018; Available Online: Mar 26, 2018. DOI: 10.15671/HJBC.2018.225

Correspondence to: B. Derkus, Dept. Biomed. Eng., Engineering Faculty, Eskisehir Osmangazi University, Eskisehir, Turkey. 


\section{INTRODUCTION}

ecently, direct fuel cells which use liquid fuels attract much more attention than the hydrogen based ones mainly because of the high cost of Graphene oxide (GO), a one-atomthick material consisting of $\mathrm{sp}^{2}$-bonded carbons, have been widely evaluated as electrocatalyst for electrochemical reactions, and as highly conductive matrix for loading catalysts of metals, and/or biological catalyzing materials such as enzymes. This conductive and electroactive material is a suitable candidate for biocatalytic reactions in which enzymes take part, thus they enable to design electrochemical biosensors having lower detection limits $[1,2]$.

Previous works show that chemisorption or contact of metallic or insulating structures affect the electronic properties of graphene or $\mathrm{GO}$ significantly $[3,4]$. While chemisorption phenomenon alters the electronic structure, it's preserved by a weak adsorption on various surfaces such as silver $(\mathrm{Ag})$ or platinum (Pt) [3]. This is a result of deviation of Fermi level from the conical points in graphene when the graphene contacts with conductive metals weakly, which is in turn doped with electrons.

Various techniques have been introduced to the literature by researchers describing the preparation of nanoparticle (NP) decorated or doped graphen oxide. To prepare graphene/metal nanoparticle composites, GO and metal salt are generally prefered as the precursors. A reduction process takes up a critical place in this method. For instance, palladium $(\mathrm{Pd}) / \mathrm{rGO}$ (reduced $\mathrm{GO}$ ) nanocomposite structure could be succesfully prepared by reducing palladium acetate to $\mathrm{Pd}$ on $\mathrm{rGO}$ [5]. Pt composite of $\mathrm{GO}$ is another widely encountered structure in this field [6]. Another commonly used technique, electrochemical deposition, enables to researchers controllable preparation of graphene/ metal nanoparticle nanostructures. Maiyalagan et al. (2012) could uniformly electrodeposited Pt nanoparticles on GO coated indium tin oxide (ITO) substrate using chloroplatinic acid salt $\left(\mathrm{H}_{2} \mathrm{PtCl}_{6}\right)$ [7]. Besides conventional methods, a considerably new technique, sonochemical method, takes attentions for graphene dopping in recent years. The superior property of ultrasound arises from acoustic cavitation, that is, the formation, growth, and implosive collapse of bubbles in liquid medium, which generates extreme reaction conditions such as $\sim 5000 \mathrm{~K}$ temperature and $\sim 1800 \mathrm{~atm}$ pressure [8]. The point is that the number of study, in which nanoparticle doped GO was synthesized sonochemically, is limited. Researchers have shown the synthesis of $G O$ doped with some nanoparticles such as $\mathrm{TiO}_{2}$ (titanium dioxide), Pt, iron(II, III) oxide $\left(\mathrm{Fe}_{3} \mathrm{O}_{4}\right)$, and lead selenide (PbSe), so far [912]. However, shapes and dimensions of those nanostructures were not as desired.

In the current study, we prepared various doped GO nanostructures namely GO-PtNPs, GOTiNPs, GO-AgNPs, and multilayer GO-AgNPs (M-GOAgNPs) using sonochemical technique. While GO-PtNPs, GO-TiNPs, and GO-AgNPs synthesis and their electrocatalytic applications exist in the literature, a multilayer nanoparticle-GO sandwich (M-GO-AgNPs in this study) was synthesized for the first time and characterized in order to enhance the peroxidase reaction. The obtained nanostructures were characterized utilizing transmission electron microscopy (TEM) and X-ray photoelectron spectroscopy (XPS), followed by preparation of modified electrodes towards to use in electrochemical hydrogen peroxide $\left(\mathrm{H}_{2} \mathrm{O}_{2}\right)$ catalysing.

\section{MATERIALS and METHODS}

\section{Materials and Apparatus}

Horse radish peroxidase (HRP), graphene oxide, chloroplatinic acid, titanium(IV) butoxide, silver nitrate $\left(\mathrm{NaNO}_{3}\right)$, sodium citrate $\left(\mathrm{Na}_{3} \mathrm{C}_{6} \mathrm{H}_{5} \mathrm{O}_{7}\right)$, hydrazine (24-26\%), hydrogen peroxide $\left(\mathrm{H}_{2} \mathrm{O}_{2}, 27 \% \mathrm{w} / \mathrm{w}\right)$, potassium chloride $(\mathrm{KCl})$, potassium ferrocyanide $\left(\mathrm{K}_{4}\left[\mathrm{Fe}(\mathrm{CN})_{6}\right]\right)$, potassiumferricyanide $\left(\mathrm{K}_{3}\left[\mathrm{Fe}(\mathrm{CN})_{6}\right]\right)$, sodium dihydrogen orthophosphate $\left(\mathrm{NaH}_{2} \mathrm{PO}_{4}\right)$, and disodium hydrogen orthophosphate $\left(\mathrm{Na}_{2} \mathrm{HPO}_{4}\right)$ were purchased from Sigma (St Louis, MO, USA). De-ionized water was purified using a Millipore Simplicity unit to a resistivity $\geq 18.2 \mathrm{M} \Omega$. Electrochemical measurements were carried out with a Gamry Instrument using Framework Version 5.50 software. OriginPro 8 was utilized for obtaining the graphs. 


\section{Synthesis of Graphene Oxide Based Nanostructures}

Four different graphene oxide based nanostructures were synthesized using sonochemical technique which gives us simple, rapid and controllable synthesis opportunity. The method presented by Giovanni et al. (2012) was modified for sonochemical synthesis of PtNPs doped GO [13]. Graphene oxide (200 mg) was redispersed in water $(20 \mathrm{~mL})$ for $15 \mathrm{~min}$, than ultrasonicated for $30 \mathrm{~min}$ in the presence of chloroplatinic acid ( $5 \mathrm{mg}$ ) under $750 \mathrm{~W}$ power and $20 \mathrm{kHz}$ frequency conditions. Lastly, the obtained PtNPs doped GO (GO-PtNPs) was dried under vacuum $\left(60^{\circ} \mathrm{C}\right)$ for $12 \mathrm{~h}$. Similarly, the method presented by Shang et al. (2014) was modified for the synthesis of GO-TiNPs. $5 \mathrm{~mL}$ of $\mathrm{GO}$ was added into $95 \mathrm{~mL}$ distilled water under ultrasonic conditions for $30 \mathrm{~min}$, folloed by dropwise addition of $\mathrm{Ti}\left(\mathrm{OC}_{4} \mathrm{H}_{9}\right)_{4}(1 \mathrm{~mL})$ slowly. $5 \mathrm{~mL}$ nitric acid (1M) was added in order to restrain $\mathrm{Ti}\left(\mathrm{OC}_{4} \mathrm{H}_{9}\right)_{4}$ hydrolysis. Finally, the product was calcified at $400^{\circ} \mathrm{C}$ for $4 \mathrm{~h}$, following solvent evaporation at $200^{\circ} \mathrm{C}(2 \mathrm{~h}) . \mathrm{GO}-\mathrm{AgNPs}$ nanostructures were prepared in one step reaction. For this purpose, $200 \mathrm{mg} \mathrm{GO}$ was dispersed in $100 \mathrm{~mL}$ of water by ultrasonication for $0.5 \mathrm{~h}$, followed by addition of $50 \mathrm{mg} \mathrm{AgNO}_{3}$. Subsequent to $1 \mathrm{~g}$ sodium citrate addition, GO-AgNPs nanostructures were formed via $1 \mathrm{~h}$ of ultrasonication. Finally, the mixture was washed with ethanol and deionized water by centrifugation, and the resulting $\mathrm{GO}$ AgNPs were dried in a vacuum oven at $60^{\circ} \mathrm{C}$ for $12 \mathrm{~h}$. Differently, $2 \mathrm{~mL}$ hydrazine (24-26\%) was added dropwise during AgNPs formation step in order to obtain GO-AgNPs multilayer structure (M-GO-AgNPs), that has been presented for the first time in this study. The mechanism is based on amid formation between carboxyl groups of $\mathrm{GO}$ and double-sided amine groups of hydrazine. Schematic presentation of GO-AgNPs and M-GOAgNPs can be seen in Figure 1. All the methods mentioned above also carry the feature of being green synthesis.

\section{Preperation of Modified Electrods}

Two different approaches were followed for the fabrication of screen-printed carbon electrods (SPCE), one of which was dropdown modification providing easy and one-step modification of materials. For this purpose, $10 \mathrm{~mL}$ of doped graphene nanostructures (GO-PtNPs, GO-TiNPs,

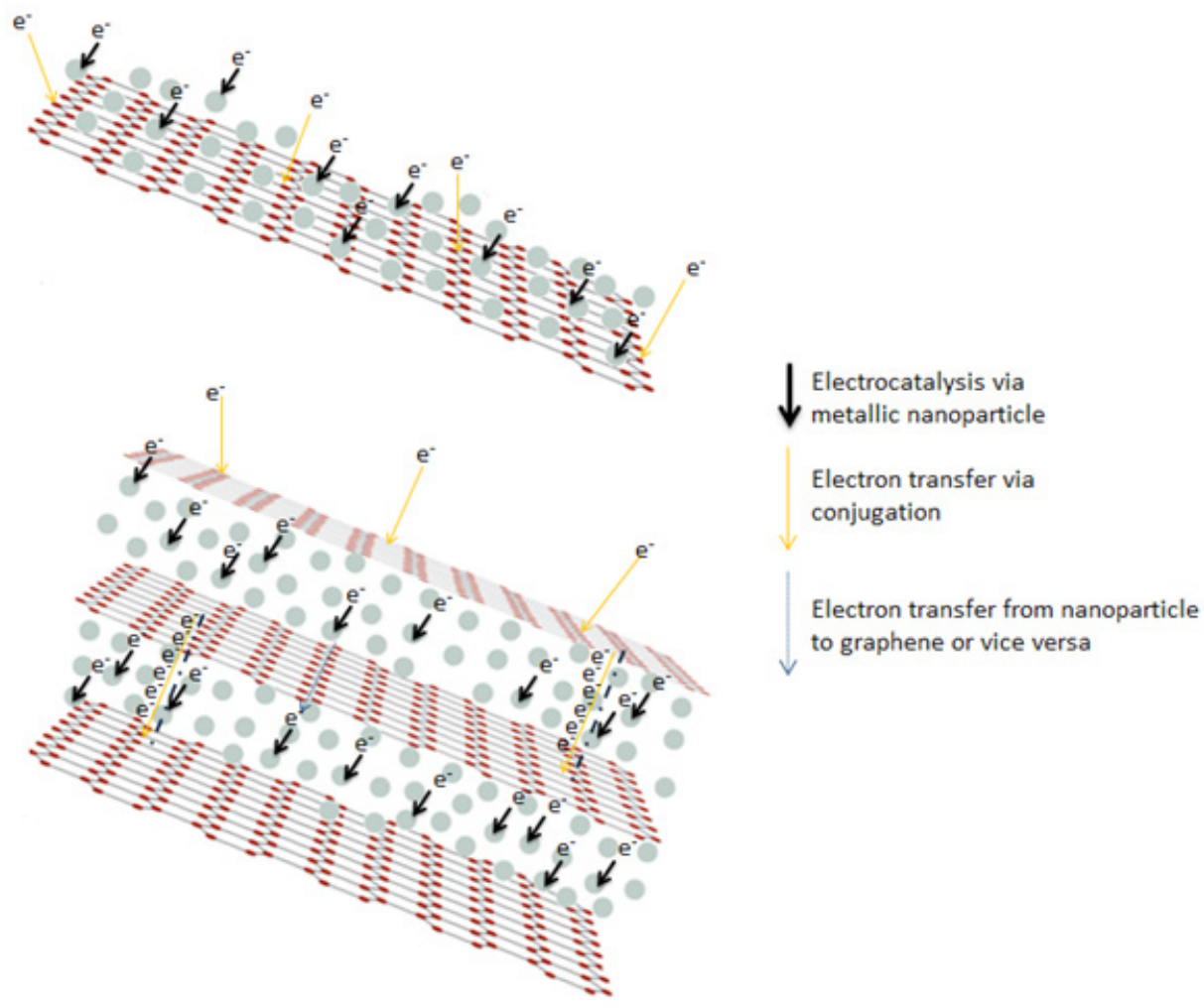

Figure 1. Schematical representation of electron transfer process in GO-AgNPs and M-GO-AgNPs. 
GO-AgNPs, and M-GO-AgNPs) was droped onto seperate SPCEs. The modified electrodes were left at room temperature for $2 \mathrm{~h}$ to ensure a stable dry surface, followed by enzyme immobilization using $10 \mathrm{~mL}$ hydrogen peroxidase (1 mg. $\left.\mathrm{mL}^{-1}\right)$. Crosslinker was not necessary owing to adhesion property of enzymes onto graphene. Enzymefree (peroxidase mimicking) electrodes were prepared using the same protocol without enzyme immobilization step. Second method includes electrodeposition of graphene based materials at $3 \mathrm{~V}$ potential. To this end, SPCEs were dipped into $1 \mathrm{~mL}$ electrochemical cell including phosphate buffer, $\mathrm{KCl}$, and nanoparticle doped graphene material, than $3 \mathrm{~V}$ potential was applied for $5 \mathrm{~min}$. Next, the electrods were washed with deionized water and dried in air. Two different approaches were carried out for enzyme immobilization. First, $10 \mathrm{~mL}$ hydrogen peroxidase $\left(1 \mathrm{mg} \cdot \mathrm{mL}^{-1}\right)$ was droped onto nanostructure electrodeposited electrodes likewise in the first method. To examine the effect of immobilization protocol on peroxide sensing, in the second method, electrodeposition was also used for entrapment of peroxidase enzyme into graphene based nanostructures. Electrochemical entrapment method has been firstly used for this kind of system in this study.

\section{Electrochemical Study}

Electrochemical measurements were carried out in a $1 \mathrm{~mL}$ electrochemical cell. In order to trigger the converison reaction, the desired concentration of hydrogen peroxide in $100 \mu \mathrm{L}$ of buffer was injected into the cell containing 0.9 $\mathrm{mL}$ total volume of buffer and $0.1 \mathrm{M} \mathrm{KCl}$. Then amperometric measurement was obtained.

$\mathrm{CV}$ and EIS were performed in PB buffer containing $0.1 \mathrm{M} \mathrm{KCl}$ and $0.5 \mathrm{mM} \mathrm{Fe}(\mathrm{CN})_{6}^{3-14}$. Cyclic voltamograms were obtained by cycling the potential between -0.4 to $0.6 \mathrm{~V}$ with a scan rate of $100 \mathrm{mVs}^{+1}$. EIS measurements were recorded within the frequency range of $0.01 \mathrm{~Hz}$ to $100 \mathrm{kHz}$ at open circuit potential.

$$
\begin{aligned}
& E p c=E^{\prime^{\prime} 0}+\frac{R T}{\alpha \operatorname{snF}}-\frac{R T}{\alpha s n F} \ln v \\
& E p a=E^{\prime^{\prime} 0}+\frac{R T}{(1-\alpha s) n F}-\frac{R T}{(1-\alpha s) n F} \ln v
\end{aligned}
$$

The electron-transfer coefficient and electrontransfer rate constant could be determined based on the Laviron theory (Equations 1 and 2) applying the scan rates of 10,50,100,200,500, and 1000 $\mathrm{mVs}^{-1}$ to the electrode system [14]:

$$
k s=\frac{\alpha n F v}{R T}
$$

where $n$ is the electron transfer number, $\mathrm{R}$ is the gas constant $\left(R=8.314 \mathrm{Jmol}^{-1} \mathrm{~K}^{-1}\right), \mathrm{T}$ is the temperature in Kelvin $(\mathrm{T}=298 \mathrm{~K}$ ) and $\mathrm{F}$ is the Faraday constant $\left(\mathrm{F}=96493 \mathrm{C} \mathrm{mol}^{-1}\right)$. When $\mathrm{n} \Delta \mathrm{Ep}>200 \mathrm{mV}$, the electron transfer rate $\mathrm{ks}$ could be estimated with the Laviron's equation (Equation 3) [14]:

\section{RESULTS and DISCUSSION}

\section{Characterization of Doped Graphene Oxide Nanostructures}

TEM and XPS analysis were performed for the detailed characterization of the nanostructures. Figure 2A shows TEM image of the synthesized GO-PtNPs nanocomposite. A large number of Pt nanoparticles with a dimension of about 4-5 $\mathrm{nm}$ were well-distributed and deposited on GO nanosheets due to hydroxyl, epoxide, and carboxylic groups existing on GO [15]. In this sonochemical assisted synthesis, Pt nanoparticles were formed by reduction of $\mathrm{H}_{2} \mathrm{PtCl}_{6}$ without adding any reducing agent, which was attributed to redox reaction between $\mathrm{GO}$ and $\mathrm{PtCl}_{6}{ }^{2-}$ and enabled a spontaneous deposition. $\mathrm{Pt}$ nanoparticles with 4-5 nm size are pretty good to be used as electrocatalyst. XPS results proved the reduction of platinic acid salt to $\mathrm{Pt}^{\circ}\left(\mathrm{Pt}_{4} \mathrm{f}_{5 / 2}\right.$ peak was observed at $74.7 \mathrm{eV}$ ) and indicated that the deposited nanoparticles were platinum indeed (Figure $3 \mathrm{~A}$ and $\mathrm{S} 1$ ). Since the Pt peak was weak, we also performed an EDAX analysis to show the presence of PtNPs using another technique. EDAX spectrum supported the XPS results and the intensive $P t$ signals suggested that the existing material was made of Pt (Figure S2). Figure $2 \mathrm{~B}$ shows the TEM image of $\mathrm{GO}-\mathrm{TiO}_{2}$ nanocomposite and helps us to understand that $\mathrm{TiO}_{2}$ nanoparticles with size of about 5-6 nm were successfully binded onto $\mathrm{GO}$. This well-dispersed nanostructure looks like an ideal candidate for electrocatalysis application. The further 


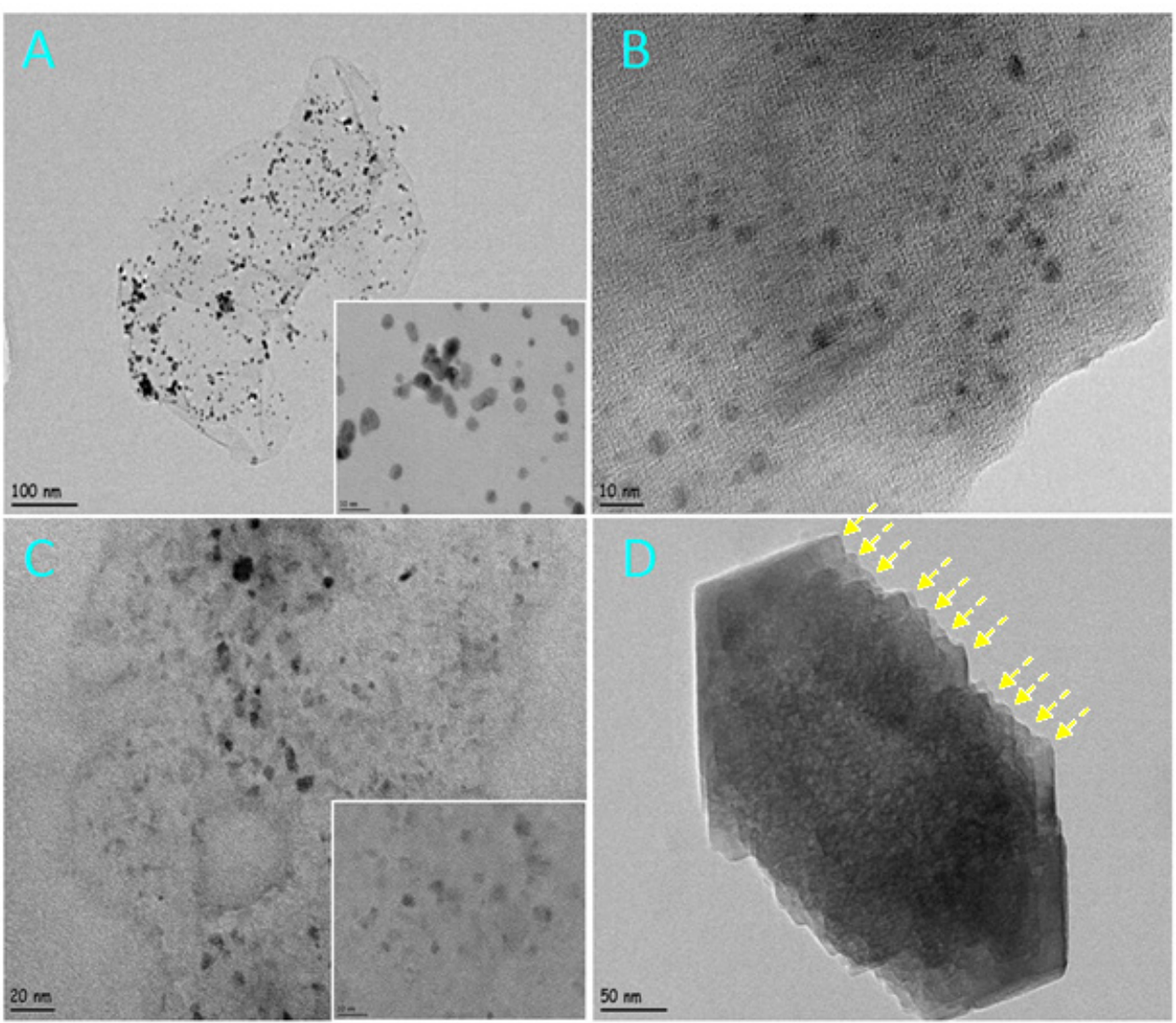

Figure 2. TEM images of (A) GO-PtNPs, (B) GO-TiNPs, (C) GO-AgNPs, and (D) M-GO-AgNPs nanostructures. The yellow arraws indicate individual $\mathrm{GO}$ nanolayers.

interaction between $\mathrm{TiO}_{2}$ and $\mathrm{GO}$ was determined by XPS as shown in Figure 3B. Two peaks located at 462.5 and $456.7 \mathrm{eV}$ took attention, which were related to $\mathrm{Ti} 2 \mathrm{p}_{1 / 2}$ and $\mathrm{Ti} 2 \mathrm{p}_{3 / 2}$ spin-orbitals, had a splitting of 5.8 that indicates the presence of anatase $\mathrm{TiO}_{2}$ (Figure 3B inset and S3 Ti2p graph) [16]. Furthermore, there were two peaks at 465.8 and $460.2 \mathrm{eV}$ that demonstrate the formation of $\mathrm{Ti}-\mathrm{O}-\mathrm{C}$ bond between $\mathrm{TiO}_{2}$ and $\mathrm{GO}$ in addition to peak centered at $282 \mathrm{eV}$ (Figure S3, C1s graph) [17]. Figure $2 \mathrm{C}$ shows the TEM image of GOAgNPs. TEM image of AgNPs/GO nanocomposite reveals that the formed silver nanoparticles with size of 4-5 $\mathrm{nm}$ are homogeneously deposied on the $\mathrm{GO}$ surface (Figure $2 \mathrm{C}$ ). When the XPS survey specta of $\mathrm{Ag}-\mathrm{GO}$ nanostructure is investigated, $\mathrm{C}=\mathrm{C}$ or $\mathrm{sp}^{2}$ component related to $\mathrm{GO}$ is seen at $284.5 \mathrm{eV}$, just as in the previous ones. Figure $3 \mathrm{C}$ and $\mathrm{S} 4$ also shows $\mathrm{Ag} 3 \mathrm{~d} 5 / 2$ and $3 \mathrm{~d} 3 / 2$ core levels at around 366 and $372 \mathrm{eV}$, respectively, corresponding to the binding energies of silver ions $\left(\mathrm{Ag}^{+}\right)$originated from $\mathrm{Ag}_{2} \mathrm{O}$ [18]. It is clear that the silver nanoparticle itself was oxidized with the reduction of $\mathrm{GO}$ simultaneously. The split between the $3 \mathrm{~d}$ doublet of $\mathrm{Ag}$ is around 6.0 $\mathrm{eV}$, suggesting the formation of metallic silver nanoparticles [19]. Similar results could be found in the literature [20]. Figure 2D shows the TEM image of multilayer GO-AgNPs nanostructure. As indicated with yellow arrows, seperate $G O$ nanosheets were binded each other via hydrazine chemistry while keeping the silver nanoparticle at the interface. Formation of a 3D structure like seen in Figure $2 \mathrm{D}$ is a proof of this concept. Although the individual AgNPs cannot be recognised in this thick structure, it can be easily observed in a less layered structure (Figure S5) that the size of the nanoparticles are nearly same with the previous one. The layers and the nanoparticles on different layers can also be recognised considering the contrast difference in this top view image. For instance, the Ag nanoparticle marked with red arrow is darker than the one marked with green. Besides, the layer indicated with yellow arrow is brighter than that indicated with blue, that also demonstrate the multilayer structure. An XPS pattern similar to GO-AgNPs is also seen in XPS diagram of M-GO-AgNPs, that shows the success 

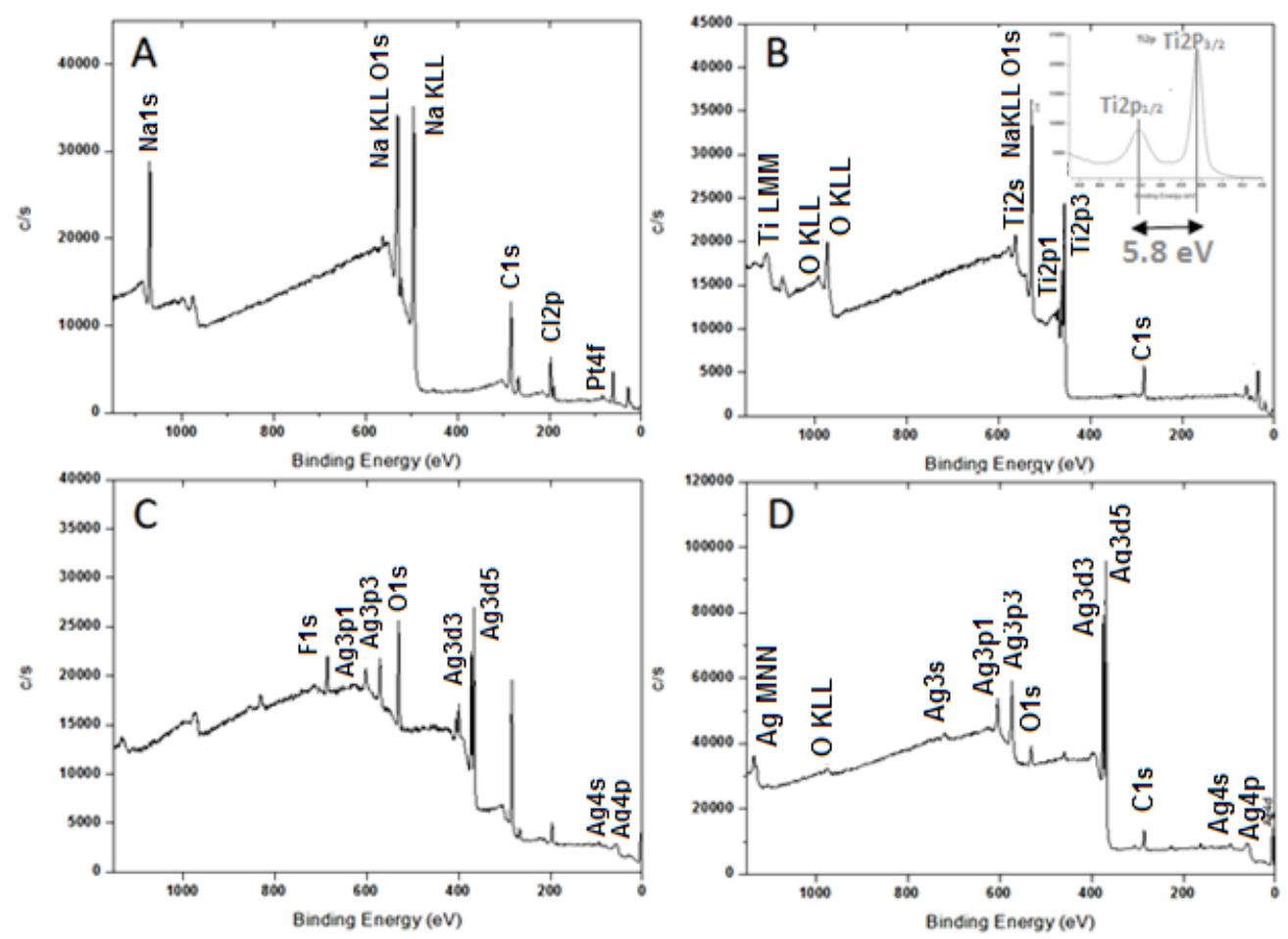

Figure 3. XPS spectra of (A) GO-PtNPs, (B) GO-TiNPs, (C) GO-AgNPs, and (D) M-GO-AgNPs nanostructures.

of formation of the nanostructure (Figure 3D and S6). The big difference in peak intensity of silver ions between GO-AgNPs (for instance, the peak intensities of $\mathrm{Ag3d}$ are c.a. 25-30.000 c/s) and M-GO-AgNPs (the peak intensities of $\mathrm{Ag} 3 \mathrm{~d}$ are c.a. $70-80.000 \mathrm{c} / \mathrm{s}$ ) supports the formation of multilayer structure, at which silver nanoparticles are entrapped between GO layers and thus improved the peak intensity of silver ions. Last of all, it can be said that all nanostructures were successfully prepared considering the XPS results.

\section{Peroxidase-Like Activity of Doped GO Nanostructures}

Obtained nanostructures were dropwise modified on SPCE in order to investigate their peroxidase-like activity. For a comperative study, nanostructure modified electrodes including HRP enzyme were aslo prepared. The amperometric responses of the electrodes against $10 \mathrm{mM} \mathrm{H}_{2} \mathrm{O}_{2}$ is seen in Figure 4.

Examining Figure 4, three main conclusions can be drawn. First, considering the metal nanoparticles doped $\mathrm{GO}$, the amperometric response of $\mathrm{Pt}$ and $\mathrm{Ag}$ doped $\mathrm{GO}$ are higher than that of $\mathrm{TiO}_{2}$ doped $G O$. This is not an unexpected result. Silver is more conductive, as commonly known, than platinum and titanium. $\mathrm{TiO}_{2}$ nanoparticle, on the other hand, is less conductive than platinum due to its semiconducture nature. GO-PtNPs modified electrode exhibits a more efficient electrochemical response than $\mathrm{GO}$ AgNPs as shown in Figure 4, which is tought to be a result of dopping efficiency diversity. Yet, this difference is too small. Secondly, a slight decrease in the amperometric response of the modified electrodes, except GO-TiNPs, was observed following the enzyme immobilization. This result is interesting and shows that the electrochemical activity of the doped GOs obtained for a $10 \mathrm{mM}$ $\mathrm{H}_{2} \mathrm{O}_{2}$ concentration is better than that uses HRP as electrocatalyst. Since enzyme immobilization also produces a resistance at the electrode surface, the enzyme-immobilized electrodes show a somewhat lower response. However, this is only true for low peroxide concentrations like $50 \mathrm{mM} \mathrm{H}_{2} \mathrm{O}_{2}$.

\section{Investigation of the Effect of Modification Techniques}

In this study, two different approaches were employed to achieve the most effective modification technique. The first technique includes dropwise addition of the prepared nanostructures onto SPCE, while the second 


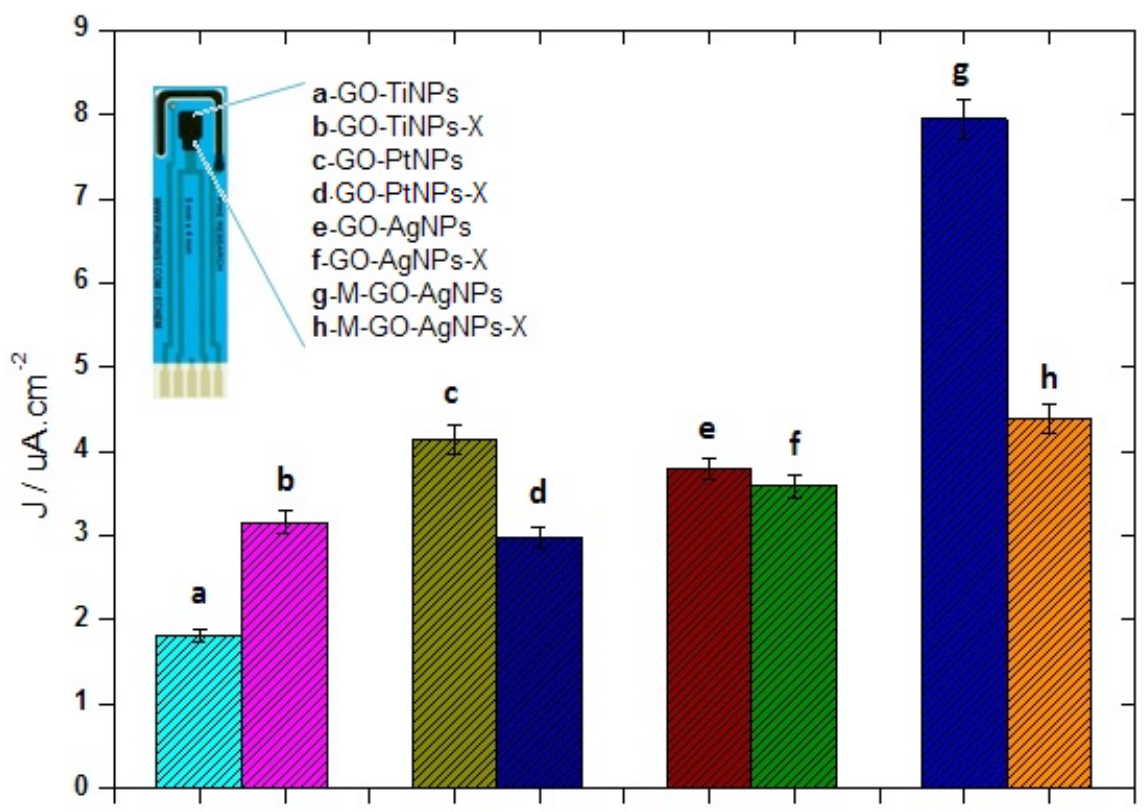

Figure 4. Amperometric responses of (a) GO-TiNPs, (b) GO-TiNPs-X, (c) GO-PtNPs, (d) GO-PtNPs-X, (e) GO-AgNPs, (f) GOAgNPs-X, (g) M-GO-AgNPs, and (h) M-GO-AgNPs-X to $10 \mathrm{mM} \mathrm{H}_{2} \mathrm{O}_{2}$.
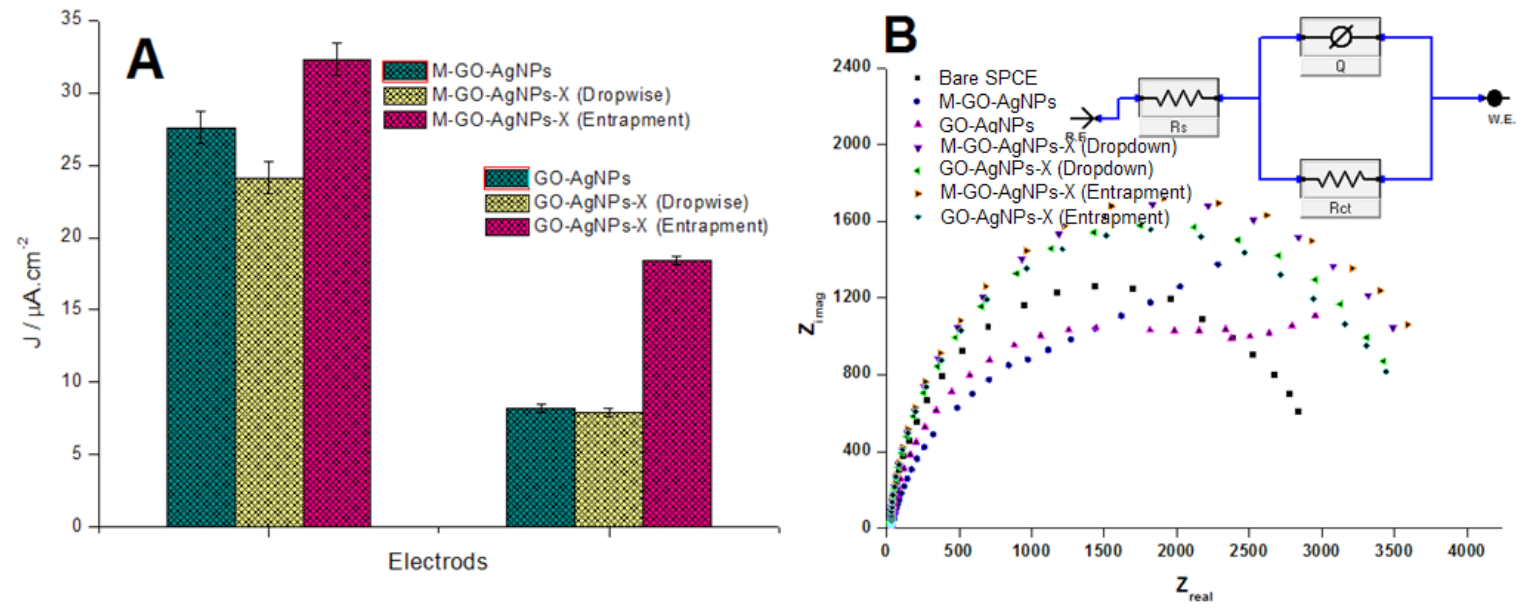

Figure 5. (A) Column graph showing amperometric responses of different enzyme immobilization methods against $50 \mu \mathrm{M}$ $\mathrm{H}_{2} \mathrm{O}_{2}$ addition: Dropwise or entrapment. (B) Impedimetric diagram showing different modification steps.

technique was based on the electrochemical entrapment of the doped $G O$ nanostructures together with enzymes. Amperometric peak intensity of the electrodes developed using dropwise addition of GO-AgNPs-X and M-GOAgNPs- $X$ were around 6 and $23.5 \mathrm{~mA}$, respectively, wherease the peak intensity of the GO-AgNPs- $X$ and M-GO-AgNPs-X electrodes prepared with electrochemical entrapment were 18 and $32 \mathrm{~mA}$ respectively (Figure $5 \mathrm{~A}$ ). Amperometric study showed that the entrapment technique enabled a more efficient enzyme immobilization compared to dropwise addition. In addition, the difference of electrochemical performance between GOAgNPs-X and M- GO-AgNPs-X can be clearly seen in this graph. Differently, the current intensity of the enzyme electrode was seen to increased when the entrapment technique was used. Nyquiste plote that is seen in Figure 5B supported the amperometric study.

\section{Electrokinetic Study}

The plots of the peak potential $\left(\mathrm{Ep}_{\mathrm{a}^{\prime}} \mathrm{Ep}_{\mathrm{c}}\right)$ vs the natural logarithm of scan rate (In) for GO- 

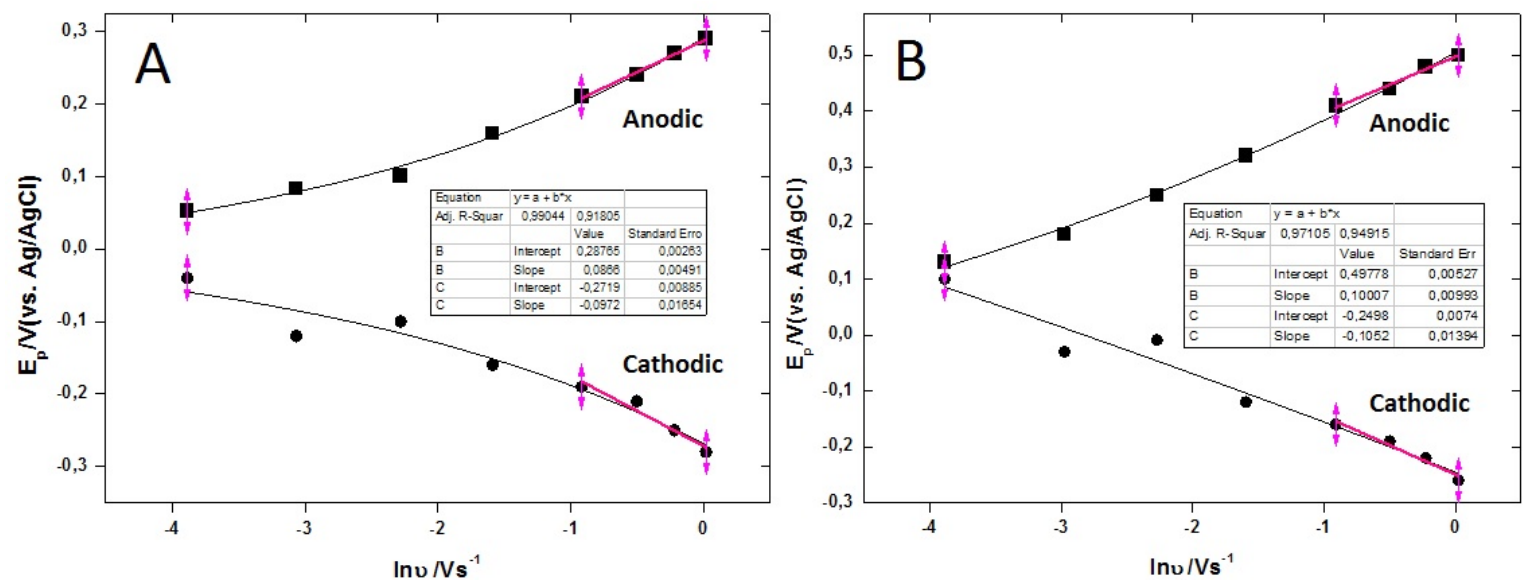

Figure 6. Inv/Ep graph related to GO-AgNPs (A) and M-GO-AgNPs (B) nanostructure modified electrode to be used for the calculation of kinetic parameters.

AgNPs (Figure 6A) and M-GO-AgNPs (Figure $6 \mathrm{~B}$ ) electrodes were obtained by $\mathrm{CV}$ in $0.5 \mathrm{mM}$ $\mathrm{Fe}(\mathrm{CN})_{6}{ }^{3-14} / 0.1 \mathrm{M} \mathrm{KCl}$ solution in the potential range of -400 to $+600 \mathrm{mV}$. Utilizing the equations above, the a values that are corresponded to electron transfer coefficients were calculated for GO-AgNPs and M-GO-AgNPs electrodes as $\mathrm{a}_{\text {cathodic, }}=0.13, \mathrm{a}_{\text {anodic }}=0.85, \mathrm{a}_{\text {cathodic }}=0.12, \mathrm{a}_{\text {anodic }}=$ 0.87 , respectively. Using Laviron's equations, the electron transfer rate constant (ks) values were calculated as $\mathrm{ks}_{\text {anodic }}=6.62 \mathrm{~s}^{-1}$ and $\mathrm{ks}_{\text {anodic }}=6.78$ $\mathrm{s}^{-1}$ for GO-AgNPs and M-GO-AgNPs, respectively. The results showed that the electron transfer rate constant of the electrode including M-GO-AgNPs to be higher than that of the other electrode. However the difference was abut 2.5\%.

\section{CONCLUSION}

Various GO based nanostructures such as GOTiNPs, GO-PtNPs, GO-AgNPs and multilayer GOAgNPs that aims to improve the electrochemical performace of enzymatic biosensors or to mimick them could be successfully synthesized using sonochemical technique and characterized in detail. The prefered amperometric method results showed that the GO-AgNPs enabled a more effective catalysis of $\mathrm{H}_{2} \mathrm{O}_{2}$. What is more, the multilayer GO-AgNPs, that is M-GO-AgNPs, was superior and showed nearly 2 times more intense amperometric response compared to other nanostructures. This electrochemical result was supported by TEM and XRD. An apparent and well ordered layer-by-layer structure was observed from TEM micrograph. In addition, having a more intensive XPS signal in multilayer structure is a proof of nanoparticle trapping. To optimize and get a better amperometric result, two different electrode modification strategy was studied. Entrapment technique was seen to more efficient in terms of catalyzing the reaction compared to dropwise modification. Finally, the M-GO-AgNPs nanostructure is tought to be used as electrochemical biosensor matrix and it's a suitable candidate for enzyme-free electrochemical sensors.

\section{References}

1. J. Liu, X. Bo, Z. Zhao, L. Guo, Highly exposed Pt nanoparticles supported on porous graphene for electrochemical detection of hydrogen peroxide in living cells, Biosens. Bioelectron., 74 (2015) 71-77.

2. Z. Liu, Y. Guo, C. Dong, A high performance nonenzymatic electrochemical glucose sensor based on polyvinylpyrrolidone-graphene nanosheets-nickel nanoparticles-chitosan nanocomposite, Talanta, 137 (2015) 87-93.

3. G. Giovannetti, P.A. Khomyakov, G. Brocks, V.M. Karpan, J. van den Brink, and P.J. Kelly, Doping Graphene With Metal Contacts, Phys. Rev. Let., 101 (2008) 268031-268034.

4. B. Uchoa, C.Y. Lin, and A.H. Castro Neto, Tailoring graphene with metals on top, Phys. Rev. B, 77 (2008) $035421-035425$.

5. G.M. Scheuermann, L. Rumi, P. Steurer, W. Bannwarth, R. Mulhaupt, Palladium nanoparticles on graphite oxide and its functionalized graphene derivatives as highly active catalysts for the Suzuki-Miyaura coupling reaction, J. Am. Chem. Soc., 131, 2009, 82628270.

6. Y. Li, L. Tang, J. Li, Preparation and electrochemical performance for methanol oxidation of pt/graphene nanocomposites, Electrochem. Commun., 11 (2009) 846-849. 
7. T. Maiyalagan, X. Dong, P. Chen, X. Wang, Electrodeposited $\mathrm{Pt}$ on three-dimensional interconnected grapheneas a free-standing electrode for fuel cell application, J. Mater. Chem., 22 (2012) 5286-5290.

8. K.S. Suslick, Ultrasound: Its chemical, physical and biological effects, VCH Verlagsgesellschaft, Weinheim, Germany, 1988.

9. B. Neppolian, C. Wang, Muthupandian Ashokkumar. Sonochemically synthesized mono and bimetallic AuAg reduced graphene oxide based nanocomposites with enhanced catalytic activity, Ultrason. Sonochem. 21 (2014) 1948-1953.

10. B. Neppolian, A. Bruno, C.L. Bianchi, M. Ashokkumar, Graphene oxide based $\mathrm{Pt}^{-\mathrm{TiO}_{2}}$ photocatalyst: Ultrasound assisted synthesis, characterization and catalytic efficiency, Ultrason. Sonochem., 19 (2012) 9-15.

11. S. Zhu, J. Guo, J. Dong, Zn Cui, T. Lu, C. Zhu, D. Zhang, J. $\mathrm{Ma}$, Sonochemical fabrication of $\mathrm{Fe}_{3} \mathrm{O}_{4}$ nanoparticles on reduced graphene oxide for biosensors, Ultrason. Sonochem., 20 (2013) 872-880.

12. L. Zhu, J.D. Chung, W.C. Oh, Rapid sonochemical synthesis of novel PbSe-graphene- $\mathrm{TiO}_{2}$ composite sonocatalysts with enhanced on decolorization performance and generation of ROS, Ultrason. Sonochem., 27 (2015) 252-261.

13. M. Giovanni, H.L. Poh, A. Ambrosi, G. Zhao, Z. Sofer, F. Sanek, B. Khezri, R.D. Webster and M. Pumera, Noble metal (Pd, Ru, Rh, Pt, Au, Ag) doped graphene hybrids for electrocatalysis, Nanoscale, 4 (2012) 5002.
14. E. Laviron, General expression of the linear potentia sweep voltammogram in the case of diffusionless electrochemical systems, J. Electroanal. Chem. 101 (1979) 19-28.

15. H.L. Wang, L.F. Cui, Y.A. Yang, H.S. Casalongue, J.T. Robinson, Y.Y. Liang, Y. Cui, H.J. Dai, J. Am. Chem. Soc., 132 (2010) 13978-13980.

16. G. Jiang, Z. Lin, C. Chen, L. Zhu, Q. Chang, N. Wang, W. Wei, H. Tang, $\mathrm{TiO}_{2}$ nanoparticles assembled on graphene oxide nanosheets with high photocatalytic activity for removal of pollutants, Carbon, 49 (2011) 2693-2701.

17. J. Guo, S. Zhu, Z. Chen, Y. Li, Z. Yu, Q. Liu, J. Li, C. Feng, D. Zhang, Sonochemical synthesis of $\mathrm{TiO}_{2}$ nanoparticles on graphene for use as photocatalyst, Ultrason. Sonochem., 18 (2011) 1082-1090.

18. E. Sumesh, M.S. Bootharaju, A.T. Pradeep, A practical silver nanoparticle-based adsorbent for the removal of $\mathrm{Hg}^{2+}$ from water, J. Hazard. Mater. 189 (2011) 450.

19. C. Gunawan, W.Y. Teoh, C.P. Marquis, J. Lifia and R. Amal, Reversible antimicrobial photoswitching in nanosilver, Small, 5 (2009) 341-344.

20. P. Prieto, V. Nistor, K. Nouneh, M. Oyama, M.A. Lefdil, R. Díaz, XPS study of silver, nickel and bimetallic silvernickel nanoparticles prepared by seed-mediated growth, Appl. Surf. Sci., 258 (2012) 8807. 